\title{
Bond Strength of Fusion Bonded Epoxy-Coated Reinforcement in Concrete
}

\author{
G. M. Sadiqul Islam ${ }^{1}$, Ehsan Ahmed², Md. Sabbir Hossain ${ }^{1}$, S. M. Sharif Uddin \\ ${ }^{1}$ Department of Civil Engineering, Chittagong University of Engineering \& Technology, Chattogram, BANGLADESH \\ ${ }^{2}$ Department of Architectural \& Engineering Technology, Thompson Rivers University, Kamloops, BC, CANADA \\ "Corresponding author: gmsislam@cuet.ac.bd
}

SUBMITTED 11 July 2019 REVISED 23 August 2019 ACCEPTED 15 September 2019

\begin{abstract}
Fusion-bonded epoxy-coated steel is expected to extend the service life of the reinforced concrete structure in chloride-laden environments. However, the effect of coating on the bond-strength between rebar and concrete is not well understood yet. This research, therefore, studied the effect of epoxy-coating on the bond characteristics of reinforcing bars in concrete. The bond characteristics were assessed through pullout test considering variables viz. concrete strength, embedded length and bar diameter. The load was applied to reinforcing bars embedded in concrete until bond strength between the bar and concrete exceeded. Bond strength of epoxy-coated bars was compared with that of the uncoated bars. It was found that epoxy-coating reduced the bond strength approximately $25 \%$ for $\varnothing 20 \mathrm{~mm}$ bar and $12 \%$ for $\varnothing 16 \mathrm{~mm}$ and $\varnothing 12 \mathrm{~mm}$ bar. As with uncoated bar, bond strength of coated bars were also increased with concrete strength. However, the bond strength ratio between coated and uncoated bars was found almost independent of concrete strength. Based on the test results, a development length modification factor of 1.33 is proposed for $\varnothing 20 \mathrm{~mm}$ bar and 1.15 for $\varnothing 12 \mathrm{~mm}$ and $\varnothing 16 \mathrm{~mm}$ bar to compensate the bond strength reduction due to the epoxy coating.
\end{abstract}

KEYWORDS Fusion-Bonded Epoxy-Coat; Steel Corrosion; Embedded Length; Bond Strength; Pullout

(C) The Author(s) 2019. This article is distributed under a Creative Commons Attribution-ShareAlike 4.0 International license.

\section{INTRODUCTION}

Reinforced concrete is a composite material in which steel is embedded in concrete in such a manner that the two materials act together in resisting forces. Performance of reinforced concrete is generally evaluated by its strength and durability properties. The most important durability issue with reinforced concrete is its deterioration due to reinforcement corrosion in an adverse environment which greatly reduce the load carrying capacity of the reinforced concrete element. The primary purpose of epoxy-coated bars is to prevent corrosion of steel, which leads to premature deterioration of concrete structures. When steel corrodes, the original volume of the material expands up to 36 times. This expansion exerts a radial pressure on the concrete, which causes cracking and spalling (Treece and Jirsa, 1989). Fusion-bonded epoxy-coated reinforcement is increasingly being used as a method of protecting steel reinforcement in concrete from corrosion. An important consideration in the use of epoxycoated bars is the effect of the coating on the bond between reinforcing bars and concrete (Breen, 2012). A major reason for the reluctance of engineers to adopt epoxy as a protective coating for reinforcing bars in key structures has been the suspicion that coated reinforcing bars might not provide acceptable bond strength in concrete. A number of studies have been carried out to investigate the behavior of coated steel bars. These includes the effect of epoxy coating of steel bars on bond strength (Clifton and Mathey, 1983; Treece and Jirsa, 1989; Cleary and Ramirez, 1991; El-Hawary, 1999; Breen, 2012), analytical calculation of bond strength of epoxy coated bar (El-Hakeem, Abd El-Aziz and ElReedi, 1997) and the effect of epoxy coating on reinforcement corrosion (Berke and Hicks, 1995; Mišković-stanković et al., 1995).

These studies have indicated epoxy-coating on reinforcement reduces bond capacity in comparison with uncoated (black) bars. Assaad and Issa, (2012) show that as compared to the uncoated bars, the decrease in bond strength was found in the range from $15 \%$ to $50 \%$ depending on several factors such as coating thickness, bar 
size and location, deformation patterns, concrete properties and casting conditions. Thus, the determination of bond strength of epoxy-coated reinforcement in concrete is a concern in many parts of the world. This study aims to investigate the bond behavior of fusion-bonded epoxycoated bar to extend the knowledge gained in the previous studies on the bond strength of coated bars in normal weight concrete.

\section{MATERIALS AND METHODOLOGY}

\subsection{Materials}

Concrete- In this study, non-air entrained normal weight concrete with CEM I of strength class $42.5 \mathrm{~N}$, stone chips and coarse sand are used. Polycarboxylic ether based retarding superplasticizer was used to achieve the target concrete compressive strengths (cube) of $15 \mathrm{MPa}$, $25 \mathrm{MPa}$ and $35 \mathrm{MPa}$ at 28 days.

Reinforcing Steel- The reinforcing steel were $\varnothing 20 \mathrm{~mm}, \varnothing 16 \mathrm{~mm}$ and $\varnothing 12 \mathrm{~mm}$ bars for both epoxy-coated and uncoated of Grade 72.5. Figure 1 show the epoxy-coated bar used in this study. Both type of steel inside concrete was subjected to uniaxial tension. The coating thickness of $\varnothing 20 \mathrm{~mm}$ bar was approximately 16 mils $(400 \mu \mathrm{m})$ and that for $\varnothing 12$ and $\varnothing 16 \mathrm{~mm}$ bars was about 7-12 mils $(175-300 \mu \mathrm{m})$ as per ASTM A934 (2016b) .

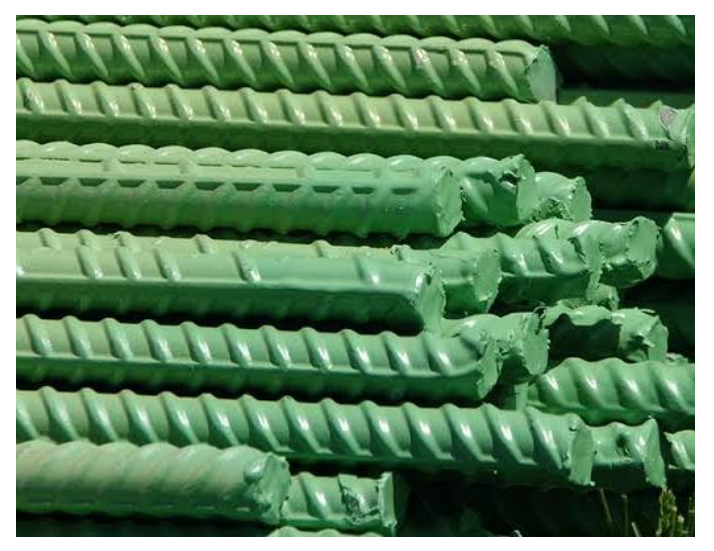

Figure 1. Epoxy coated steel used in this study

\subsection{Experimental Program}

Concrete samples were mixed and the slump was confirmed. Once desired slump was achieved the fresh concrete was poured in cylindrical steel mould to prepare samples for pull out and compressing strength tests. After curing for 28 days the samples were tested for compressive and bond strength. To evaluate the bond strength of fusion-bonded epoxy-coated steel with concrete, pullout test is conducted in the laboratory. The cylindrical specimen dimension was $\emptyset 100 \mathrm{~mm} \times 200 \mathrm{~mm}$ for $\emptyset 12 \mathrm{~mm}$ and $\emptyset 16 \mathrm{~mm}$ bar and $\emptyset 150 \mathrm{~mm} \times 300 \mathrm{~mm}$ for the $20 \mathrm{~mm}$ bar. Embedded lengths of the bars were $75 \mathrm{~mm}$ and $300 \mathrm{~mm}$ for $\emptyset 12 \mathrm{~mm}$ bar, $100 \mathrm{~mm}$ and $200 \mathrm{~mm}$ for $\emptyset 16 \mathrm{~mm}$, and $150 \mathrm{~mm}$ and $250 \mathrm{~mm}$ for $\emptyset 20 \mathrm{~mm}$ bar. The samples sizes were taken based on previous studies (ASTM A994; Bazant and Sener, 1988; Islam and Naha, 2015). While embedded lengths are taken independently for other bars, this was $250 \mathrm{~mm}$ for $\emptyset 20 \mathrm{~mm}$ bar in a cylindrical prism of $\emptyset 150 \mathrm{~mm} \times 300 \mathrm{~mm}$ was taken according to ASTM A775 (2017). All pullout tests were carried out in a $2000 \mathrm{kN}$ capacity Universal Testing Machine (UTM). A typical pullout specimen positioned on the testing machine is shown in Figure 2.
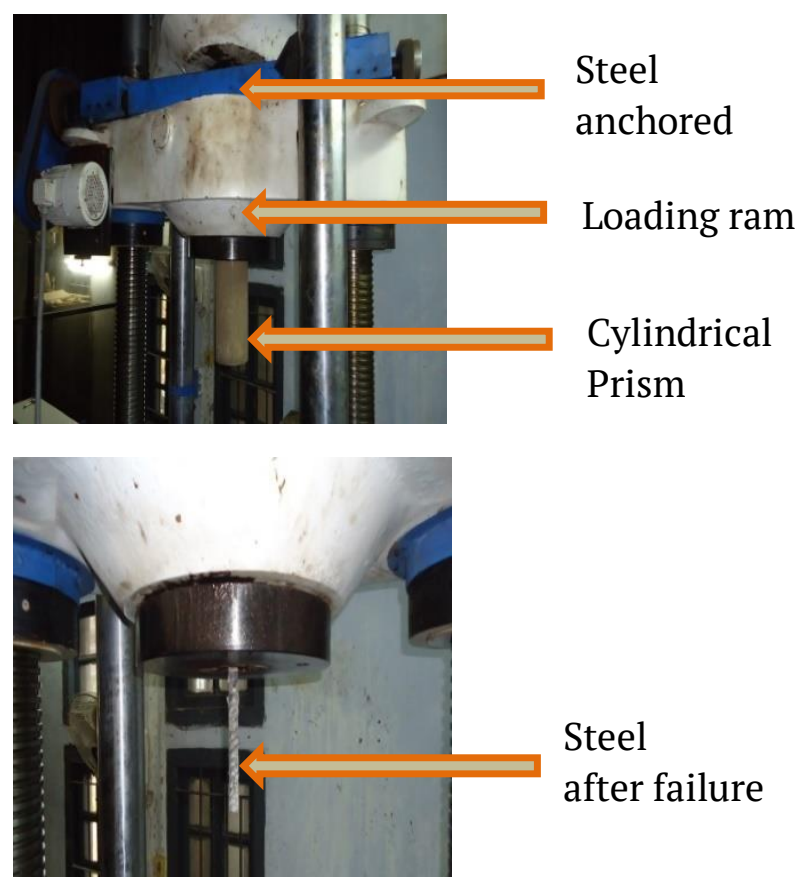

Figure 2. Pullout test with UTM

\section{RESULT AND DISCUSSION}

\subsection{Effect of Compressive Strength}

3.1.1 Ø20mm bar - embedded 150mm and 250mm

Test results of $\varnothing 20 \mathrm{~mm}$ bar embedded $150 \mathrm{~mm}$ and $250 \mathrm{~mm}$ in different strength concretes are 
shown in Tables 1 and 2 . The failure mode of the cylindrical prism is pullout for $150 \mathrm{~mm}$ embedded length in $\mathrm{C} 15$ concrete and splitting for all other cases. For each concrete strength failure mode was similar for both coated and uncoated rebars. It is seen that the average bond strength ratio between coated and uncoated bar is 0.67 at the embedded length of $150 \mathrm{~mm}$ and 0.75 at the embedded length of $250 \mathrm{~mm}$, i.e. strength reduction is about $33 \%$ and $25 \%$ respectively. As shown in Figures 3 and 4, the bond strength increased linearly with concrete strength.

However, bond strength increased with embedded length (see Figure 5). It is observed that the strength reduction curves are almost parallel to the horizontal axis i.e. strength reduction is independent of the concrete strength, though the failure mode was different for lower grade concrete.

Table 1. Bond strength of $20 \mathrm{~mm}$ bar (embedded $150 \mathrm{~mm}$ ) in $\Phi 150 \times 300$ concrete cylinder

\begin{tabular}{ccccc}
\hline $\begin{array}{c}\text { Concrete } \\
\text { Grade }\end{array}$ & $\begin{array}{c}\text { Bar } \\
\text { type }\end{array}$ & $\begin{array}{c}\text { Failure } \\
\text { mode }\end{array}$ & $\begin{array}{c}\text { Bond } \\
\text { Strength, } \\
\text { MPa }\end{array}$ & $\begin{array}{c}\text { Bond } \\
\text { Strength } \\
\text { Ratio C/U }\end{array}$ \\
\hline \multirow{2}{*}{ C15 } & $\mathrm{U}$ & $\mathrm{P}$ & 11.85 & 0.69 \\
& $\mathrm{C}$ & $\mathrm{P}$ & 8.16 & \\
$\mathrm{C} 25$ & $\mathrm{U}$ & $\mathrm{S}$ & 14.75 & 0.67 \\
& $\mathrm{C}$ & $\mathrm{S}$ & 9.33 & \\
$\mathrm{C} 35$ & $\mathrm{U}$ & $\mathrm{S}$ & 16.34 & 0.68 \\
& $\mathrm{C}$ & $\mathrm{S}$ & 11.24 & \\
\hline
\end{tabular}

$\mathrm{U}=$ Uncoated, $\mathrm{C}=$ Coated, $\mathrm{P}=$ Pullout failure, $\mathrm{S}=$ Splitting failure

Table 2. Bond strength of $20 \mathrm{~mm}$ bar (embedded $250 \mathrm{~mm}$ ) in $\Phi 150 \times 300$ concrete cylinder

\begin{tabular}{ccccc}
\hline $\begin{array}{c}\text { Concrete } \\
\text { Grade }\end{array}$ & $\begin{array}{c}\text { Bar } \\
\text { type }\end{array}$ & $\begin{array}{c}\text { Failure } \\
\text { mode }\end{array}$ & $\begin{array}{c}\text { Bond } \\
\text { Strength, } \\
\text { MPa }\end{array}$ & $\begin{array}{c}\text { Bond } \\
\text { Strength } \\
\text { Ratio C/U }\end{array}$ \\
\hline \multirow{2}{*}{ C15 } & U & S & 8.94 & 0.75 \\
& C & S & 6.68 & \\
C25 & U & S & 10.98 & 0.75 \\
& C & S & 8.28 & \\
C35 & U & S & 11.77 & 0.76 \\
\hline
\end{tabular}

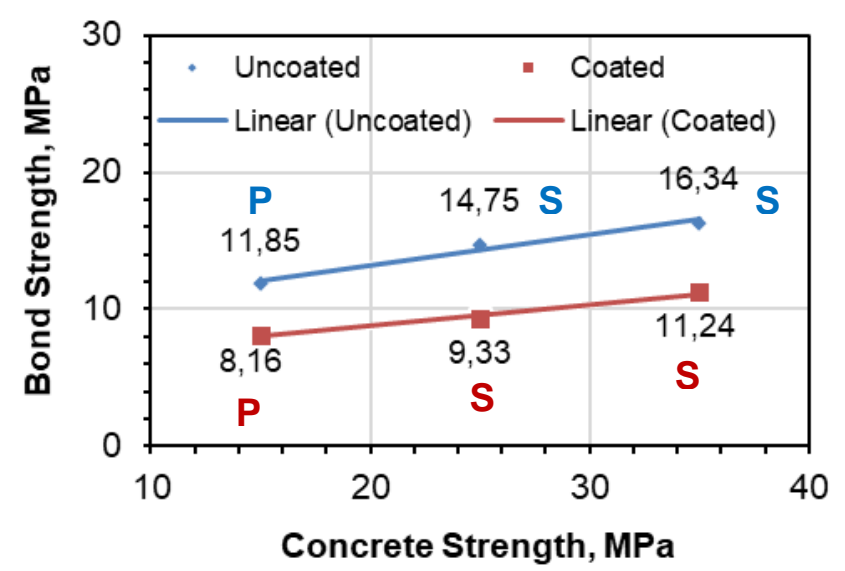

Figure 3. Variation of bond strength with different strength concrete (Ø20 $\mathrm{mm}$ bar and $150 \mathrm{~mm}$ embedded length)

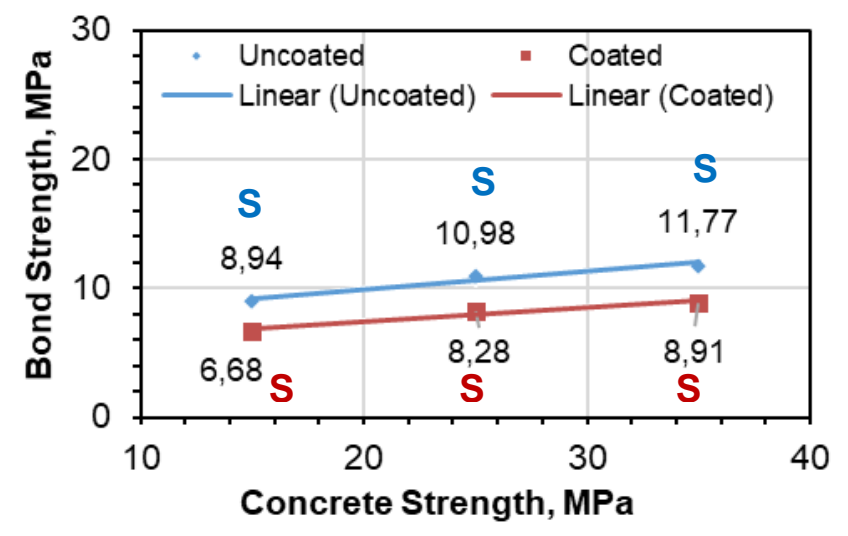

Figure 4. Variation of bond strength with different strength concrete (Ø20 $\mathrm{mm}$ bar and $250 \mathrm{~mm}$ embedded length)

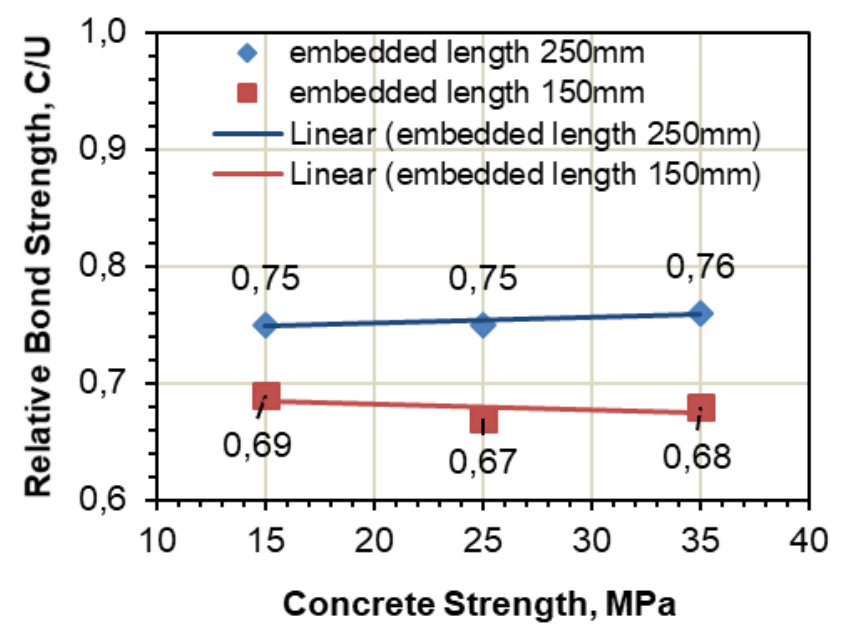

Figure 5. Reduction in bond strength with different embedded length (Ø20 mm bar). 


\subsection{2 Ø16mm bar - embedded 100mm and $200 \mathrm{~mm}$}

Test results of $\varnothing 16 \mathrm{~mm}$ diameter bar at an embedded length of $100 \mathrm{~mm}$ and $200 \mathrm{~mm}$ in different concrete strength are shown in Tables 3 and 4 . The failure mode of the cylindrical prism is pullout inside $\mathrm{C} 15$ concrete at the embedded length of $100 \mathrm{~mm}$ (uncoated bars) and splitting for all other cases. It is seen that the average bond strength ratio between coated and uncoated bar is 0.80 at the embedded length of $100 \mathrm{~mm}$ and 0.88 at the embedded length of $200 \mathrm{~mm}$, i.e. strength reduction is about $20 \%$ and $12 \%$ respectively.

Table 3. Bond strength of $16 \mathrm{~mm}$ bar (embedded $100 \mathrm{~mm}$ ) in \$100×200 concrete cylinder

\begin{tabular}{ccccc}
\hline $\begin{array}{c}\text { Concrete } \\
\text { Grade }\end{array}$ & $\begin{array}{c}\text { Bar } \\
\text { type }\end{array}$ & $\begin{array}{c}\text { Failure } \\
\text { mode }\end{array}$ & $\begin{array}{c}\text { Bond } \\
\text { Strength, } \\
\text { MPa }\end{array}$ & $\begin{array}{c}\text { Bond } \\
\text { Strength } \\
\text { Ratio C/U }\end{array}$ \\
\hline \multirow{2}{*}{ C15 } & U & P & 6.04 & 0.83 \\
& C & S & 5.05 & \\
C25 & U & S & 13.27 & 0.79 \\
& C & S & 10.42 & \\
C35 & U & S & 15.91 & 0.78 \\
\hline
\end{tabular}

Table 4. Bond strength of $16 \mathrm{~mm}$ bar (embedded $200 \mathrm{~mm}$ ) in \$100×200 concrete cylinder

\begin{tabular}{ccccc}
\hline $\begin{array}{c}\text { Concrete } \\
\text { Grade }\end{array}$ & $\begin{array}{c}\text { Bar } \\
\text { type }\end{array}$ & $\begin{array}{c}\text { Failure } \\
\text { mode }\end{array}$ & $\begin{array}{c}\text { Bond } \\
\text { Strength, } \\
\text { MPa }\end{array}$ & $\begin{array}{c}\text { Bond } \\
\text { Strength } \\
\text { Ratio } \\
\text { C/U }\end{array}$ \\
\hline $\mathrm{C} 15$ & $\mathrm{U}$ & $\mathrm{S}$ & 6.4 & 0.90 \\
& $\mathrm{C}$ & $\mathrm{S}$ & 5.82 & \\
$\mathrm{C} 25$ & $\mathrm{U}$ & $\mathrm{S}$ & 10.54 & 0.88 \\
& $\mathrm{C}$ & $\mathrm{S}$ & 9.3 & \\
$\mathrm{C} 35$ & $\mathrm{U}$ & $\mathrm{S}$ & 11.64 & 0.88 \\
\hline
\end{tabular}

Also, it can be concluded that bond strength increases linearly with concrete strength as shown in Figures 6 and 7. However, a minor decrease in bond strength ratio is noted with embedded length (see Figure 8). As with Ø20mm bar, the strength reduction curves are almost parallel to the horizontal axis i.e. strength reduction is independent of concrete strength.

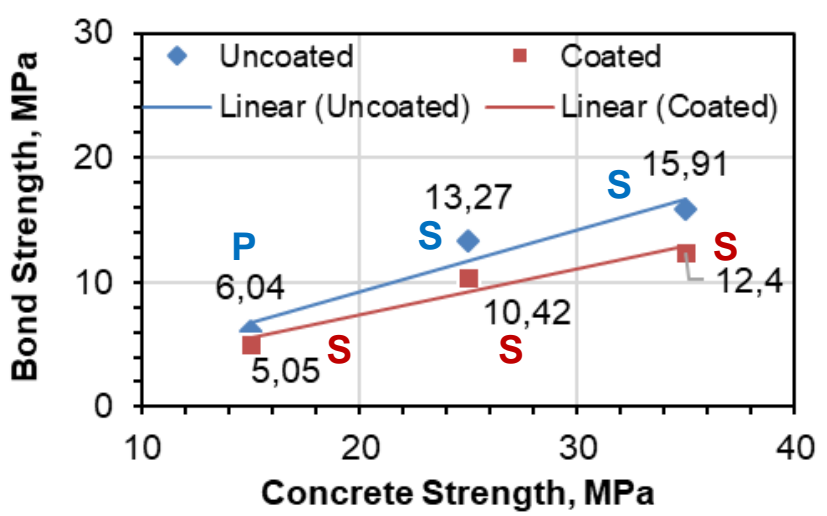

Figure 6. Variation of bond strength with different strength concrete ( $\varnothing 16 \mathrm{~mm}$ bar and $100 \mathrm{~mm}$ embedded length)

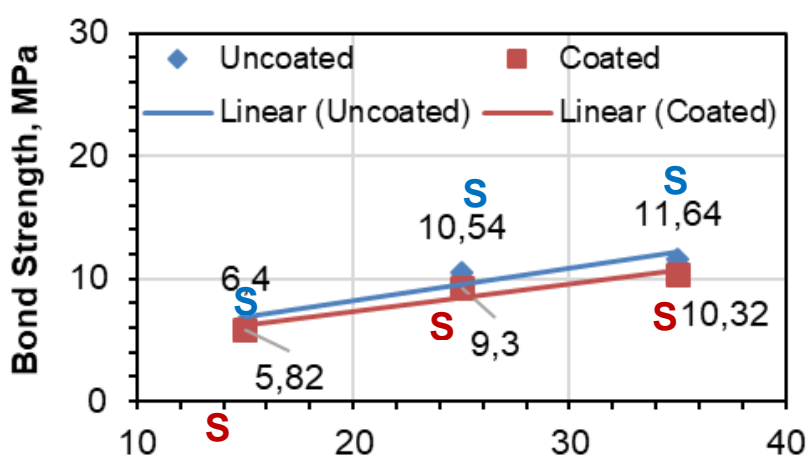

Concrete Strength, MPa

Figure 7. Variation of bond strength with different strength concrete ( $\varnothing 16 \mathrm{~mm}$ bar and $200 \mathrm{~mm}$ embedded length)

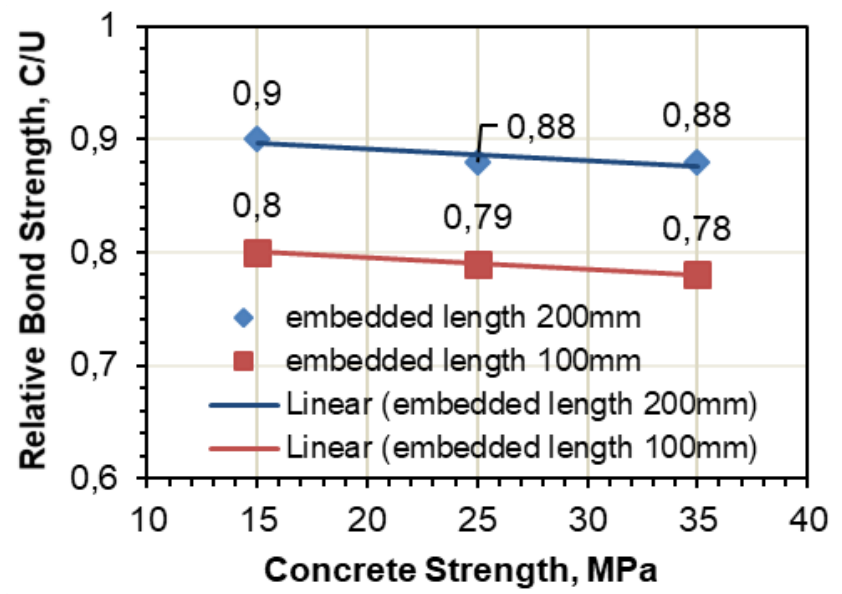

Figure 8. Reduction in bond strength with different embedded length $(\varnothing 16 \mathrm{~mm}$ bar)

\subsection{3 Ø12mm bar - embedded $75 \mathrm{~mm}$ and $150 \mathrm{~mm}$}

Test results of $\varnothing 12 \mathrm{~mm}$ bars embedded $75 \mathrm{~mm}$ and $150 \mathrm{~mm}$ in different strength concretes are shown in Tables 5 and 6. Pullout failure of cylindrical specimens is found for $15 \mathrm{MPa}$ concretes while this was splitting for all other cases. 
The average bond strength ratio between coated and uncoated bar is found 0.85 for the embedded length of $75 \mathrm{~mm}$ and that is 0.88 for $150 \mathrm{~mm}$ embedded length. This indicates strength reduction is about $15 \%$ and $12 \%$ respectively. As with earlier test results for $\varnothing 16 \mathrm{~mm}$ and $\varnothing 20 \mathrm{~mm}$ bars, it can be concluded that bond strength increase linearly with concrete strength as shown in Figures 9 and 10.

Table 5. Bond strength of $12 \mathrm{~mm}$ bar (embedded $75 \mathrm{~mm}$ ) in $\Phi 100 \times 200$ concrete cylinder

\begin{tabular}{ccccc}
\hline $\begin{array}{c}\text { Concrete } \\
\text { Grade }\end{array}$ & $\begin{array}{c}\text { Bar } \\
\text { type }\end{array}$ & $\begin{array}{c}\text { Failure } \\
\text { mode }\end{array}$ & $\begin{array}{c}\text { Bond } \\
\text { Strength, } \\
\text { MPa }\end{array}$ & $\begin{array}{c}\text { Bond } \\
\text { Strength } \\
\text { Ratio C/U }\end{array}$ \\
\hline \multirow{2}{*}{ C15 } & U & P & 11.31 & 0.85 \\
& C & P & 9.62 & \\
C25 & U & S & 19.66 & 0.84 \\
& C & S & 17.68 & \\
C35 & U & S & 21.29 & 0.86 \\
& C & S & 18.40 & \\
\hline
\end{tabular}

Table 6. Bond strength of $12 \mathrm{~mm}$ bar (embedded $150 \mathrm{~mm}$ ) in $\Phi 100 \times 200$ concrete cylinder

\begin{tabular}{ccccc}
\hline $\begin{array}{c}\text { Concrete } \\
\text { Grade }\end{array}$ & $\begin{array}{c}\text { Bar } \\
\text { type }\end{array}$ & $\begin{array}{c}\text { Failure } \\
\text { mode }\end{array}$ & $\begin{array}{c}\text { Bond } \\
\text { Strength, } \\
\text { MPa }\end{array}$ & $\begin{array}{c}\text { Bond } \\
\text { Strength } \\
\text { Ratio C/U }\end{array}$ \\
\hline \multirow{2}{*}{ C15 } & U & P & 16.98 & 0.88 \\
& $\mathrm{C}$ & $\mathrm{P}$ & 14.85 & \\
$\mathrm{C} 25$ & $\mathrm{U}$ & $\mathrm{S}$ & 21.50 & 0.89 \\
& $\mathrm{C}$ & $\mathrm{S}$ & 19.45 & \\
$\mathrm{C} 35$ & $\mathrm{U}$ & $\mathrm{S}$ & 24.75 & 0.88 \\
& $\mathrm{C}$ & $\mathrm{S}$ & 21.92 & \\
\hline
\end{tabular}

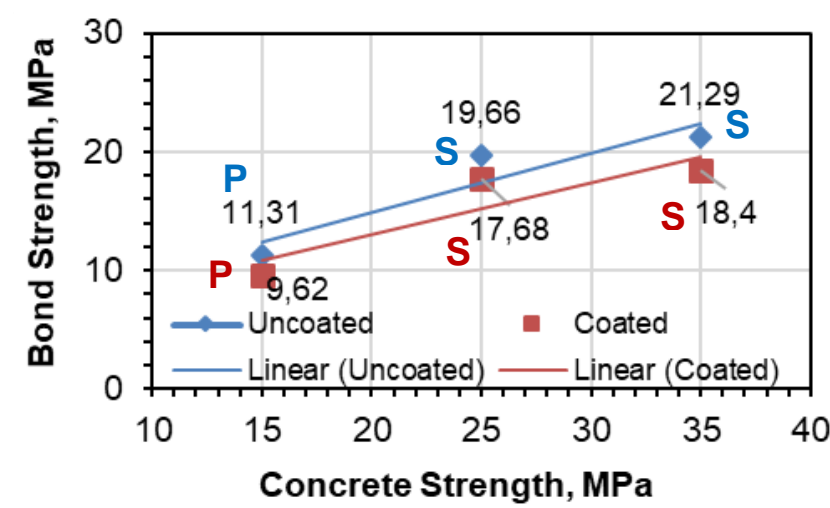

Figure 9. Variation of bond strength with different strength concrete $(\varnothing 12 \mathrm{~mm}$ bar and $75 \mathrm{~mm}$ embedded length)

However, the strength reduction is decreased with embedded length (Figure 11). The effect of embedment length on bond strength has been addressed in earlier (Kayali and Yeomans, 2000) studies which are in agreement with the results obtained in this study. Kayali and Yeomans (2000) also reported that the bond strength of $\varnothing 16 \mathrm{~mm}$ black and galvanized steel are 19\% and $26 \%$ greater than that of epoxy coated steel in concrete, respectively. The results are also consistent with the results of this study. It is observed that the strength reduction curves follow the same trend as before and are almost parallel to the horizontal axis which indicates that the strength reduction is independent of the concrete strength.

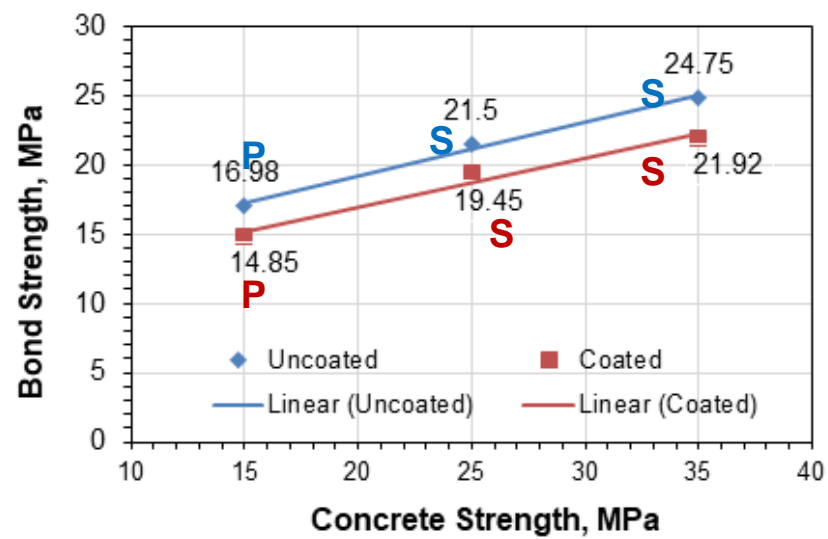

Figure 10. Variation of bond strength with different strength concrete $(\varnothing 12 \mathrm{~mm}$ bar and $150 \mathrm{~mm}$ embedded length)

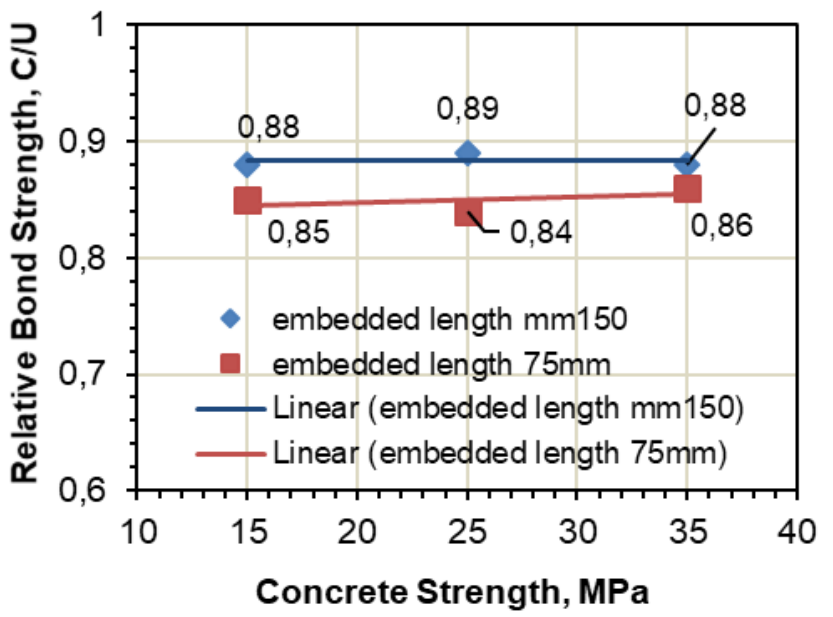

Figure 11. Reduction in bond strength with different embedded length ( $\varnothing 12 \mathrm{~mm}$ bar)

\subsection{Bond Strength Reduction with Bar Size}

The bond strength reductions remain almost the same for $\varnothing 12 \mathrm{~mm}$ and $\varnothing 16 \mathrm{~mm}$ bars, however, a sudden increase of bond strength reduction was found for the $20 \mathrm{~mm}$ bar. From the analysis, it is seen that strength reduction is about $12 \%$ for both $\varnothing 12 \mathrm{~mm}$ and $\varnothing 16 \mathrm{~mm}$ bars at the embedded length of $150 \mathrm{~mm}$ and $200 \mathrm{~mm}$ and $25 \%$ for $20 \mathrm{~mm}$ 
diameter bar at the embedded length of $250 \mathrm{~mm}$. The strength reduction with the sizes of the bar is shown in Figure 12. This increase in bond strength reduction for higher diameter bar is mainly attributed to the thickness of the coating on the bar.

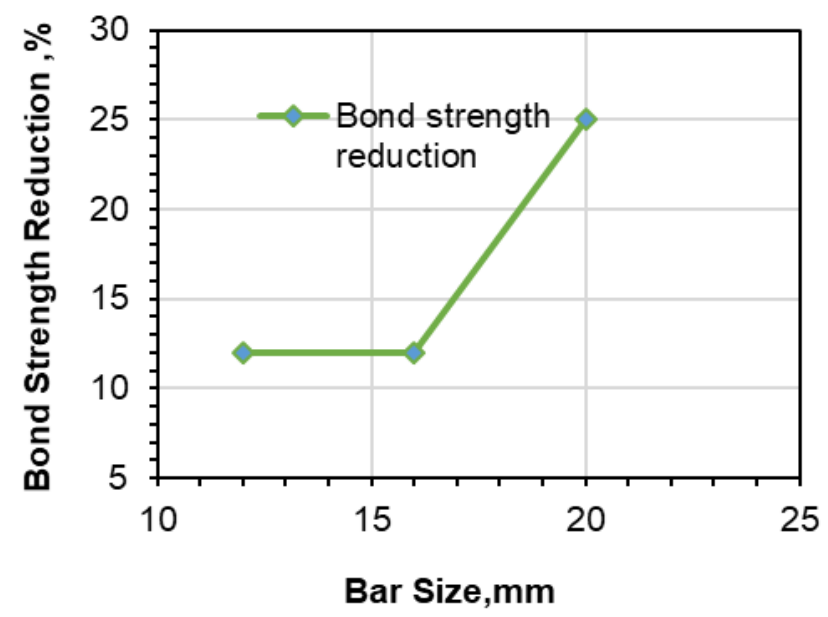

Figure 12. Bond strength reduction with bar size

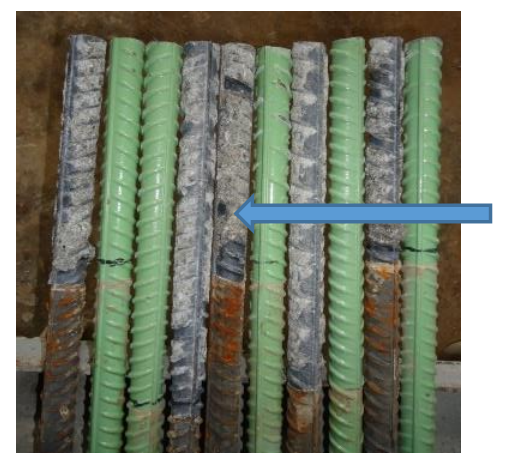

Concrete

Adhesion

Figure 13. $\varnothing 20 \mathrm{~mm}$ bar surface

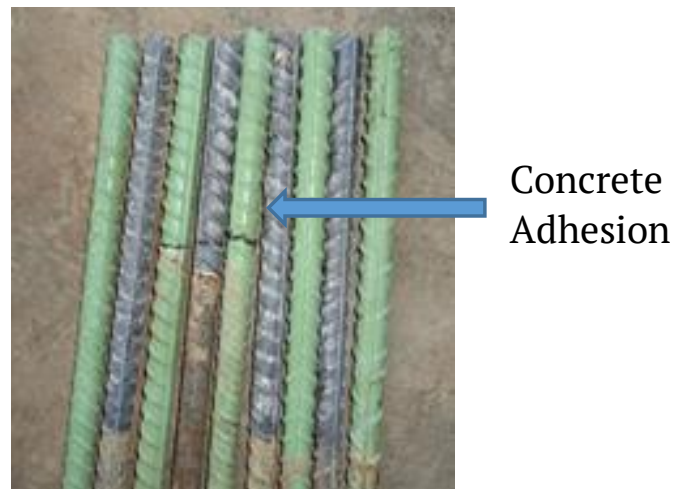

Figure 14. $\varnothing 16 \mathrm{~mm}$ bar surface

It was reported (Miller, Kepler and Darwin, 2003) that the coating thickness has a significant impact on the reduction of bond strength. The coating thickness for $20 \mathrm{~mm}$ diameter bar is about 16 mils $(400 \mu \mathrm{m})$ and for $\varnothing 12$ and $\varnothing 16 \mathrm{~mm}$ is about 7 to 12 mils (175 to $300 \mu \mathrm{m}$ ).

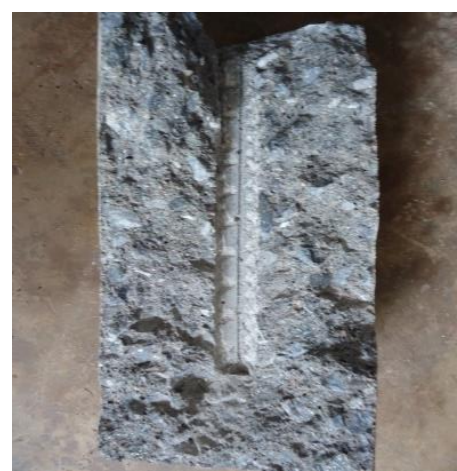

Figure 15. $\varnothing 20 \mathrm{~mm}$ bar Bond surface in cylinder specimen

One of the significant reason of an increase in bond strength reduction for larger diameter bar is the more adhesion property of uncoated larger diameter bar with concrete than uncoated lower diameter bar, but the adhesion property is almost same for all coated bars, which has observed after the pullout test. So the loss of adhesion is higher for $\varnothing 20 \mathrm{~mm}$ bar than $\varnothing 12 \mathrm{~mm}$ and $\varnothing 16 \mathrm{~mm}$ bars. The relative adhesion property of uncoated bars is shown in Figures 13-16.

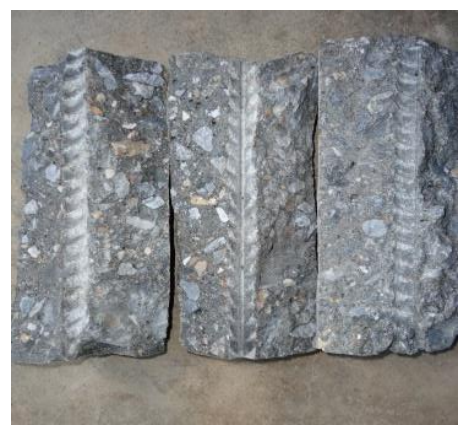

Figure 16. $\varnothing 16 \mathrm{~mm}$ bar Bond surface in cylinder specimen

\subsection{Loss of Adhesion}

The loss of adhesion between epoxy-coated reinforcement and concrete has been documented (Kazakov and Yanakieva, 2009). The concrete in direct contact with epoxy-coated bars had smooth, glassy surface and coated bar appeared clean, with no concrete residual left on the rib dales (see Figures 17). On the other hand, the uncoated bar shown in Figure 17 has mortars attached on its surface indicating better adhesion between concrete and rebars.

The concrete surface in (refer to Figure 18) direct contact with the uncoated bar was dull and rough, and uncoated bars that were removed from the concrete had concrete particles 
attached to the shaft, deposited on rib dales (see Figure 19).

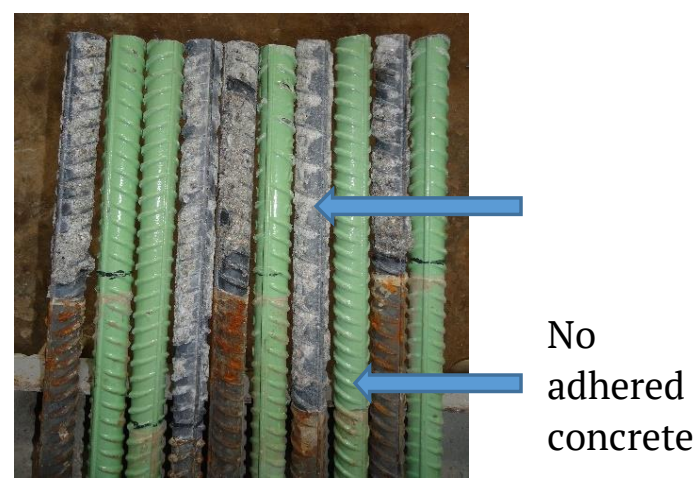

Figure 17. Steel Surface after pullout failure

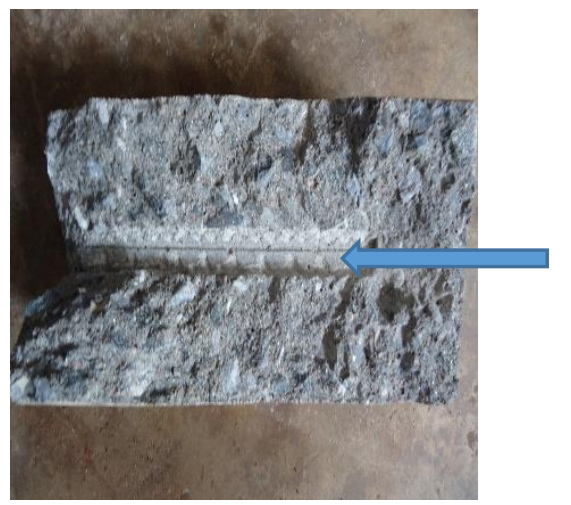

Rough

bond

surface

Figure 18. Concrete bond surface (uncoated)

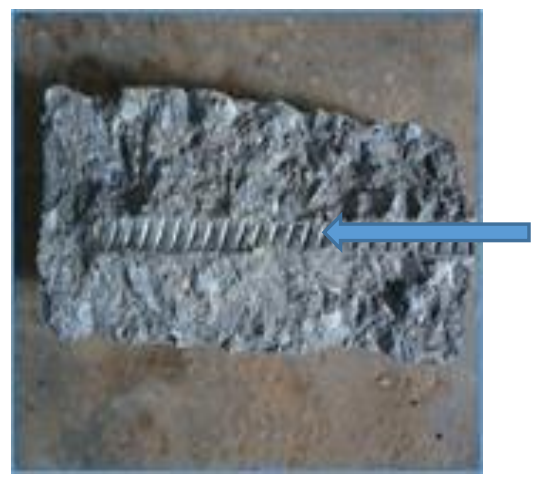

Smooth

bond

surface

Figure 19. Concrete bond surface (coated)

\section{CONCLUSION}

Considering the type of deformation pattern, the type and the thickness of coating material the following conclusion can be drawn based on the results and analysis on the pullout test on coated and uncoated bars in concrete:

a) Bond strength reduction for $20 \mathrm{~mm}$ diameter bar is approximately $33 \%$ and $25 \%$ at an embedded length of $150 \mathrm{~mm}$ and $250 \mathrm{~mm}$; whereas for $16 \mathrm{~mm}$ diameter bar the strength reduction is about $20 \%$ and $12 \%$ at embedded length of $100 \mathrm{~mm}$ and $200 \mathrm{~mm}$; and for $12 \mathrm{~mm}$ diameter bar the strength reduction is about $14 \%$ and $12 \%$ at embedded length of $75 \mathrm{~mm}$ and $150 \mathrm{~mm}$ respectively. It is concluded that the bond strength increases with embedded length.

b) Based on the larger embedded length, average strength reduction is $25 \%$ for $\emptyset 20 \mathrm{~mm}$ bar and $12 \%$ for $\emptyset 16 \mathrm{~mm}$ and $\emptyset 12 \mathrm{~mm}$ bar i.e bond strength reduction varies with the bar size.

c) For all bar sizes considered in this study, the bond strength ratio between coated and uncoated bars slightly in different grade concretes i.e bond strength reduction due to coating is independent of concrete strength. However, for both coated and uncoated bars, the overall bond strength increased with the concrete strength.

d) Pullout failure occurs in low strength concrete and splitting failure occurs in high concrete strength.

The loss in bond strength due to the introduction of the epoxy coating was found to be within tolerable limit. By applying some design modification, it is possible to use the epoxy coated bar for durable reinforced concrete production. The development length could be increased to mitigate the loss of bond strength. Alternately, the manufacturer can use a relatively large rib bearing area by changing the bar deformation pattern, as the strength reduction decreases with the increase of rib bearing area (Choi et al., 1991). To widespread the use of fusion bonded epoxy-coated bar the above factors should be considered during design.

\section{DESIGN IMPLICATIONS}

Based on the test results, to apply the epoxycoated bars, a development length modification factor of 1.33 for $\emptyset 20 \mathrm{~mm}$ bar and 1.15 for $\emptyset 16 \mathrm{~mm}$ and $\emptyset 12 \mathrm{~mm}$ are proposed from this study. 


\section{ACKNOWLEDGEMENT}

The authors acknowledge the laboratory assistance of Department of Civil Engineering, Chittagong University of Engineering and Technology. Thanks extended to 'BSRM' for providing epoxy-coated rebars from the production lot.

\section{REFERENCES}

Assaad, J. J. and Issa, C. A. (2012) 'Bond strength of epoxy-coated bars in underwater concrete', Construction and Building Materials, 30, pp. 667674. doi: 10.1016/j.conbuildmat.2011.12.047.

ASTM A775 (2017) 'Standard specification for epoxy-coated reinforcing steel bars', ASTM International, West Conshohocken, USA.

ASTM A934/A934M-04 (2016b) 'Standard specification for epoxy-coated reinforcing steel bars', Valsper 720A009 Greenbar, USA.

ASTM A994 (2016a) 'Standard test method for comparing bond strength of steel reinforcement bars to concrete using beam-end specimens', ASTM International, West Conshohocken, USA.

Bazant, Z. P. and Sener, S. (1988) 'SIZE EFFECT IN PULLOUT TESTS.', ACI Materials Journal, 85(2), pp. 347-351.

Berke, N. S. and Hicks, M. C. (1995) 'Calcium nitrite corrosion inhibitor with and without epoxy-coated reinforcing bar for long term durability in the gulf', in. Bahrain: Proceedings of the Concrete Durability in the Arabian Gulf Conference, pp. 119-132.

Breen, J. E. (2012) 'Techniques for Improving Durability of Post-Tensioned Concrete Bridges', Arabian Journal for Science and Engineering, 37(2), pp. 303-314. doi: 10.1007/s13369-0120184-7.

Choi, O. C. et al. (1991) 'Bond of epoxy-coated reinforcement: bar parameters', ACI Materials Journal, 88(2), pp. 207-217.

Cleary, D. B. and Ramirez, J. A. (1991) 'Bond strength of epoxy-coated reinforcement', ACI Structural Journal, 88(2), pp. 146-149.
Clifton, J. R. and Mathey, R. G. (1983) 'Bond And Creep Characteristics Of Coated Reinforcing Bars In Concrete.', Journal of the American Concrete Institute, 80(4), pp. 288-293.

El-Hakeem, F. A., Abd El-Aziz, M. I. and ElReedi, M. A. (1997) 'Calculating bond strength of coated and uncoated steel bars using an analytical model', in. Kuwait: Proceedings of the Seventh Arab Structural Engineering Conference, pp. 247-256.

El-Hawary, M. M. (1999) 'Evaluation of bond strength of epoxy-coated bars in concrete exposed to marine environment', Construction and Building Materials, 13(7), pp. 357-362. doi: 10.1016/S0950-0618(99)00042-2.

Islam, A. and Naha, A. (2015) Evaluation of bond strength of epoxy coating steel in concrete. Chittagong University of Engineering \& Technology, Bangladesh.

Kayali, O. and Yeomans, S. R. (2000) 'Bond of ribbed galvanized reinforcing steel in concrete', Cement and Concrete Composites, 22(6), pp. 459467. doi: 10.1016/S0958-9465(00)00049-4.

Kazakov, K. and Yanakieva, A. (2009) 'Finite element method numerical simulation and ductile capacity analysis of bond-slip between epoxy coated plain steel bars and concrete', in WIT Transactions on Engineering Sciences. doi: 10.2495/SECM090201.

Miller, G. G., Kepler, J. L. and Darwin, D. (2003) 'Effect of epoxy coating thickness on bond strength of reinforcing bars', ACI Structural Journal, 100(3), pp. 314-320.

Mišković-stanković, V. B., Dražić, D. M. and Teodorović, M. J. (1995) 'Electrolyte penetration through epoxy coatings electrodeposited on steel', Corrosion Science, 37(2), pp. 241-252. doi: 10.1016/0010-938X(94)00130-X.

Treece, R. A. and Jirsa, J. O. (1989) 'Bond strength of epoxy-coated reinforcing bars', ACI Materials Journal, 86(2), pp. 167-174. 